WwW.iibpas.com

\title{
MICROBIAL DEGRADATION OF ORGANOPHOSPHORUS COMPOUNDS: A
} REVIEW

\section{PRASAD S AND SINGH R*}

School of Bioengineering and Biosciences, Lovely Professional University, Phagwara, Punjab

*Corresponding Author: Rattandeep Singh: E Mail: drrattandeep@gmail.com

Received 16 ${ }^{\text {th }}$ March 2021; Revised 17 ${ }^{\text {th }}$ April 2021; Accepted $24^{\text {th }}$ May 2021; Available online $1^{\text {st }}$ Feb. 2022

\section{https://doi.org/10.31032/IJBPAS/2022/11.2.5857}

\begin{abstract}
In developing nations like India executes a pivotal role in agriculture and their significance in progress of crop yield is comprehended and very much acknowledged. The organophosphorus compounds are utilized as pesticides, plasticizers and for different things. Organophosphorus compounds are generally utilized as insecticides by which $34 \%$ of these pesticides are utilized around the world. Leaching of pesticides from farm causes soil and ground water contamination. Some reports revealed that the wide scope of water and earthbound biological system might be affected by organophosphorus compounds. Bioremediation can offer an ideal alternative for decontamination of contaminated ecosystem. Flavobacterium spp. was the first microorganism isolated in 1973 has the ability to degrade organophosphates. Many bacterial and fungal species have been isolated which can degrade organophosphates in soil as well as in submerged conditions. Subsequently the current paper audits the adequacy and usefulness of bioremediation technique for detoxification of organophosphorus compounds in soil. This review also include the isolation of those bacteria which can degrade the organophosphorus compounds from the soil.
\end{abstract}

Keywords: Pesticides, Organophosphorus compounds, contamination, Bioremediation INTRODUCTION

India is the agro based nation, through which agriculture is the primary asset of living for the greater part of its population. Along these lines so as to meet the prerequisites for food 
and to take care of the developing population, the high amount of pressure is applied on the agriculture area [1]. The major ecological worry of utilized pesticides is their ability to eliminate the dirt and affect the ground water [2]. On the other hand, if fixed, they would persevere on the top soil where it could gather to poisonous level in the soil and become destructive to micro-organisms, plants, creatures and man [3]. The unnecessary utilization of natural resources and huge amount of production of xenobiotic compounds have created various ecological issue, for example, contamination of air, water and earthbound ecosystem [4]. At present time organophosphorus compounds are broadly utilized pesticides. Tetraethyl pyrophosphate was the first discovered and used organophosphorus insecticide in the year 1937 [5]. These pesticides are broadly utilized around the world to overcome farming as well as house hold pests. Generally, organophosphorus compounds represent $\sim 38 \%$ of absolute pesticides utilized all inclusive [6]. To overcome the body pest of animals some compounds are used are known to be organophosphates. But sometimes some of the body pests are soluble in fats and because of that they are able to enter inside the body via skin and conceivably find their path to milk as well as meat [7]. Around 2 lakh tons of high poisonous organophosphorus chemical warfare agents were developed and stored namely soman, sarin, and VX.

The convenient research on xenobiotics degradation by using microorganisms shows lots of reviews which express few features. The crucial premise of biodegradation, transformation and relocate such action between some micro-organisms and techniques like bioremediation is to decontaminate polluted conditions [8]. Nonetheless, utilization of microbes for bioremediation required a comprehension of microbiological, environmental, biochemical, physiological and molecular conditions associated with toxin change [9]. Two kinds of xenobiotics are there i.e DDT and Carbofuran. An efficient implication of augmented biodegradation relies upon various associated components like the utilization of the pesticides and their abundance of utilization. In recent times, $\mathrm{pH}$ of the soil suggests as to be the involved in improving atrazine degradation in numerous soil fields [10] which proposed that it is responsible for affecting degradation rate by influencing the absorption of the herbicides with the help of soil microbes.

Isolation of pesticide degrading microorganisms is significant for following primary reasons: 
(1). To influence metabolism of microorganisms and their mechanism.

(2). To comprehend the developmental process of genes and enzymes.

(3). To utilize these microorganisms for the soil detoxification and to clean the marine as well as earthbound territory [11].

\section{Classification of Pesticides: -}

Pesticides are classified according to their mode of action to be named contact or nonsystemic as well as systemic pesticides [12]. The non-systemic or on the other hand, surface pesticides utilized in recent years were potent just at surface level. Conversely, a considerable lot of the present pesticides can successfully enter the cuticle of the plant and travel through the vascular systems which are named to be herbicides, organophosphorus insecticides, fungicides etc. Contrary to the non-systemic pesticides not only secure the plant from parasites, but it also recovers or rather prohibit a set of diseases. Inferable from their systemic pesticides, they are probably more particular in their harmfulness than non-systemic pesticides. However, Systemic pesticide performs an essential role in the accomplishment of green reformation whereas the period between 1960 to 1970 is known to be the golden period for the engineered pesticides [13].

\section{Microbial degradation of organo- phosphoruscompounds: -}

Utilization of organochlorine pesticides, for example, dichloro-diphenyltrichloroethane (DDT), lindane, and so on., has been diminished definitely in some countries because of their long perseverance, inclination with regards to bioaccumulation and harmfulness regarding non-target entities.

Compounds like esters consist of numerous bonds that are susceptible against hydrolysis. In these reactions, it involves hydrolysis, oxidation, alkylation and de-alkylation [14]. Pesticide degradation by micro-organisms through the hydrolysis P-O Alkyl as well as P-O Aryl bonds seems to be most crucial stage in detoxification. Hydrolysis of organophosphates causes a decrease in their mammalian toxicity. They have ability to induce distinctly without any requirement of inorganic phosphate throughout growth medium. The enzyme alkaline phosphatase in several pathways can hydrolyze monoalkylphosphates [15]. The manner by which metabolism is directed depends emphatically on what task the organophosphates does especially for the specific microbes. In 1988, Scientist named Shelton [16] found out a 
group of such bacteria's that uses Diethylthiophosphoric acid either as

Diethylthiophosphoric acid as carbon source, phosphorus or sulfur source.

however these bacteria cannot use

Table 1: Properties of world widely used Organophosphate pesticides

\begin{tabular}{|c|c|c|c|c|c|c|c|}
\hline $\begin{array}{c}\text { Name of } \\
\text { Organophosphorus } \\
\text { Pesticides }\end{array}$ & $\begin{array}{l}\text { Hazard Class } \\
\text { according to } \\
\text { WHO }\end{array}$ & $\begin{array}{l}\text { Carcinogenic } \\
\text { Nature of } \\
\text { pesticides }\end{array}$ & $\begin{array}{c}\text { Mammalian } \\
\text { oral LD50 } \\
\text { (mg/kg) }\end{array}$ & $\begin{array}{c}\text { Mammalian } \\
\text { dermal LD50 } \\
(\mathbf{m g} / \mathbf{k g})\end{array}$ & $\begin{array}{c}\text { Solubility in } \\
\text { Water } \\
\text { (mg/L) }\end{array}$ & $\begin{array}{l}\text { Half-life in } \\
\text { soil at } 20^{\circ} \mathrm{C} \\
\text { (Days) }\end{array}$ & $\begin{array}{l}\text { Half-life in } \\
\text { water. } \\
\text { (Days) }\end{array}$ \\
\hline Acephate & II & Possible & $361-1400$ & - & $8.2 \times 10^{5}$ & $4.5-32$ & 169 \\
\hline Chlorpyrifos & II & Not likely & $32-1000$ & 2000 & 1.18 & 30.5 & 2118 \\
\hline Coumaphos & Ia & Not likely & 13-80 & $500-2400$ & 1.5 & 152 & - \\
\hline Diazinon & II & Not likely & $26-300$ & 379 & 60 & 40 & 138 \\
\hline Dichlorvos & II & - & $56-108$ & $75-210$ & $1 \times 10^{4}$ & - & - \\
\hline Dicrotophos & Ib & Possible & $15-22$ & - & $1 \times 10^{6}$ & 5 & 72 \\
\hline Dimethoate & II & Possible & 235 & $>400$ & $3.9 \times 10^{4}$ & $2-22$ & 68 \\
\hline Ethion & II & Not likely & 208 & 838 & 2.0 & 90 & 146 \\
\hline Ethoprophos & Ia & High & 61 & 26 & $8.5 \times 10^{2}$ & 34-130 & 449 \\
\hline Fenamiphos & Ib & Not likely & 10 & $>2000$ & $4.82 \times 10^{2}$ & $24-88$ & 301 \\
\hline Fenitrothion & II & Not likely & 500 & 1416 & 19 & 2.7 & 183 \\
\hline Fenthion & II & Not likely & $180-298$ & $330-1000$ & 4 & - & 41 \\
\hline Isofenphos & Ib & Not likely & 28 & 188 & 24 & 150 & 365 \\
\hline Malathion & III & Possible & 5500 & $>4000$ & $1.3 \times 10^{2}$ & 3-3.5 & 6 \\
\hline Monocrotophos & Ib & No evidence & $17-20$ & 126 & $8.2 \times 10^{5}$ & 7 & 134 \\
\hline Parathion & Ia & Possible & $2-50$ & 6.8 & 13 & $21-58$ & 302 \\
\hline Phorate & II & Not likely & $2-4$ & $20-30$ & 29 & $3-14$ & 3 \\
\hline Phosphamidon & Ia & Possible & 13-20 & 26 & $1 \times 10^{6}$ & 1 & 65 \\
\hline Profenophos & II & Not likely & 358 & 1610 & 28 & $2-3$ & 43 \\
\hline Quinalphos & II & No evidence & $62-137$ & $1250-1400$ & 17.8 & 21 & 39 \\
\hline Terbufos & Ia & Not likely & $2-10$ & - & 4.5 & 8 & 6.5 \\
\hline Tetrachlorvinphos & - & High & $4000-8600$ & - & 11.6 & 2 & - \\
\hline Triazophos & Ib & No evidence & $57-59$ & $>2000$ & 35 & 44 & 140 \\
\hline
\end{tabular}

Bacterial Degradation of Most Widely Used Organophosphorus Compounds: -

- Chlorpyrifos: -

Chlorpyrifos is among the best utilized insecticides compelling across the wide range of insect pests of significant harvests. This insecticide is effective when one can come in contact, ingestion and fume activity however it isn't fundamentally dynamic. Basically chlorpyrifos is utilized to overcome the mosquitoes (hatchlings as well as grownups), flies, different soil and numerous foliar crop pests along with household pests. Additionally, it is utilized to overcome the ecto-parasites on cows and sheep. It is soluble in water but in low amount ( $2 \mathrm{mg} / \mathrm{L})$, yet is promptly dissolvable in lots of natural solvents. It is highly absorbed by soil via coeffective manner [17] furthermore is steady when present in typicalstate.

The natural effect of chlorpyrifos is contemplated broadly. Debasement of microbes in soil includes chemical breakdown as well as bacterial action. With 
regards to soil, the life span of chlorpyrifos differs from 10 to 120 days [18]. As it consists 3, 5, 6-trichloro-2-pyridinol (TCP) as the significant degradable item. This enormous variety time period has been ascribed to various ecological components, generally significant are temperature, moisture content, natural carbon substance, soil $\mathrm{pH}$ as well as pesticide definition [19].

\section{Diazinon: -}

Diazinon (O, O-diethyl O-[6-methyl-2-(1methylethyl-4-pyrimidinyl)] ester) is a bug spray utilize to overcome cockroaches, silverfish, bugs and ants. It is additionally usually utilized in home nurseries and on ranches to control a wide assortment of leafeating bugs [20]. It is normally present in granules, dusts, wettable powders and seed dressings [21]. It is highly soluble in water. As indicated by the characterization of WHO (2009), it is dangerous as well as its an class II toxic compound. Time period of Diazinon in the soil is approx 40 days and 138 days in the water [23].

\section{Parathion: -}

Parathion (O,O-diethyl-O-p-nitrophenyl phosphorothioate) is among the most harmful insecticides. It is enrolled with the US Environmental Protection Agency (EPA). Outrageous harmfulness with an easily introduction has brought about various human along withuntarget species passing in a new creating nations [24]. The microbial debasement of parathion has gotten broad consideration between the organophosphates on account of its far reaching utilized furthermore the prepared location of its hydrolytic product. By using biologically active soil Parathion can simply degradedby utilizing benzenetriol oxygenase.

\section{- Fenamiphos:-}

Fenamiphos (ethyl 4-methylthio-m-tolyl isopropylphosphoramidate) is known to be aorganophosphorate utilized widely utilized to overcome soil nematodes. Fenamiphos is fundamental, dynamic acrossecto-and endoparasitic, cist forming as well as root knod nematodes. The solubility of water at $37^{\circ} \mathrm{C}$ is $700 \mathrm{mg} / \mathrm{L}$. The acute oral LD50 for rodents is $15.3-19.4 \mathrm{mg} / \mathrm{kg}$ just as $10 \mathrm{mg} / \mathrm{kg}$ for dogs [25].

Fenamiphos quickly degraded from both enhanced as well as from non-increased soils yet FSO2 is seldom framed in augmented soils [26]. This recommends improved biological deterioration of fenamiphos, the poisonous particles were because of an expansion in the vanishing FSO rate in soil tests gathered from land locales treated a couple of successive occasions with fenamiphos [27]. Ou \& Thomas in 1994 found out first microbial groups containing 
six different bacterial species which can able to degrade fenamiphos in fluid medium. Brevibacterium spp. MM1 culture has ability to hydrolyzed fenamiphos and does not uses its biproduct as energy source. Two groups of bacteria with different strains, first group containing four bacterial strains and another containing five bacterial strains were isolated from Australian soils can uses fenamiphos as a single source of energy as carbon and nitrogen. In comparison, out of the groups segregated by Ou \& Thomas (1994), two of them namely CRF as well as BEP unable to utilize supplementary nutrient source to degrade fenamiphos where they can survive in liquid medium without mineral surface [28].

\section{CONCLUSION}

organophosphorus compounds degradation has pulled significant recognition due to the high utilization of pesticides and their high mammalian poisonousness. An enormous number of microorganisms have been isolated that are having ability to degrade organophosphorus compounds by means of Bio-stimulation. A few microorganisms can degrade compounds however some microbes can carry out the degradation of organophosphates because of the hydrolysis of organophosphates which then decreases harmfulness or toxicity in warm blooded animals. Employments of microorganisms for the detoxification of these harmful synthetic substances being a significant technique from an efficient and ecological perspective. The utilization of genetically modified microbes for the degradation of pesticides has risen as amazing strategy for in-situ bioremediation. This review gives the information collected by some scientists with regard to microbial degradation of organophosphorus compounds and it will efficient for those analysts who will work in future on this topic.

\section{REFERENCES}

[1] Mishra A, J amaluddin and Pandey AK. Microbial degradation of organophpsphorus Pesticide: Methyl Parathion. Austin J biotechnol. Bioeng, 2017, Volume 4 Issue 1 $-2017$.

[2] Kookana RS, Baskaran S, Naidu R. Pesticide fate and behaviour in Australian soils in relation to contamination and management of soil and water: a review. Aust. J. Soil Res, 1998, 36, 715-764.

[3] Amakiri MA. Microbial degradation of soil applied herbicide. Nig. J. Microbial, 2, 17-21.

[4] Cook AM, Daughton CG \& Alexander M. Phosphonate utilization by bacteria. J Bacteriol, 1978a, 133, 85 -90.

[5] Dragun J, Kuffner AC \& Schneiter RW. Groundwater contamination. 1. Transport and transformation of organic chemicals. Chem Eng, 1984, 91, 65-70. 
[6] Post. Organophosphate (Post note 12). Parliamentary Office of science and Technology, London, UK, 1998.

[7] MAFF/HSE. Annual report of the working party on pesticide residue. HMSO, 1995.

[8] Singh BK \& Kuhad RC. Biodegradation of lindane by the white-rot fungus Trametes hirsutus. Lett Appl Microbiol, 1999, 28, 238241.

[9] Iranzo M, Sain-Pardo I, Boluda R, Sanchez J $\&$ Mormeneo S. The use of microorganisms in environmental remediation. Annals Microbiol, 2001, 51, 135-143.

[10] Houot S, Topp E, Yassir A \& Soulas G. Dependence of accelerated degradation of atrazine on soil $\mathrm{pH}$ in French and Canadian soils. Soil Biol Biochem, 2000, 32, 615-625.

[11] Brajesh K. Singh \& Allan Walker. Microbial degradation of organophosphorus compounds. Environmental science, 2006, 428471.

[12] Cremlyn. Pesticides preparation and mode of action. John Wiley and sons, Ltd.USA, 1978, 1-240.

[13] Estevez MA, Periogo EL, Carbello EM, Gandara JS, Juan-Carlos Mejuto, Luis García-Río. The mobility and degradation of pesticides in soils and pollution of groundwater resources. Agriculture, Ecosystems and Environment, 2008, 123, 247-260.

[14] Singh BK \& Kuhad RC. Biodegradation of lindane by the white-rot fungus Trametes hirsutus. Lett Appl Microbiol, 1999, 28, 238-241.

[15] Wolfenden R \& Spence G. Depression of phosphomonoesterase and phosphodiesterase activities in Aerobacter aerogenes. BiochemBiophys Acta, 1967, 146, 296-298.

[16] Getzin LW. Degradation of chlorpyrifos in soil: influence of autoclaving, soil moisture, and temperature. J Econ Entomol, 1981a, 74, 158-162.

[17] Getzin LW. Dissipation of chlorpyrifos from dry soil surfaces. J Econ Entomol, 1981b, 74, 707-713.

[18] Chapman RA \& Chapman PC. Persistence of granular and EC formulation of chlorpyrifos in a mineral and an organic soil incubated in open and closed containers. J Environ Sci Health B, 1986, 21, 447-456.

[19] Sethunathan N \& Yoshida T. $A$ flavobacterium that degrades diazinon and parathion. Can J Microbiol, 1973, 19, 873875.

[20] Price OR, Walker A, Wood M \& Oliver MA. Using geostatistics to evaluate spatial variation in pesticide/soil interactions. Pesticide Behaviour in Soil and Water (Walker A, ed.), Proceeding of a BCPC Symposium, 2001, 78, 233-238.

[21] Singh BK, Walker A, Morgan JAW \& Wright DJ. Effect of soil $\mathrm{pH}$ on the biodegradation of chlorpyrifos and isolation of a chlorpyrifos-degrading bacterium. Appl Environ Microbiol, 2003c, 69, 5198-5206. 
[22] Grube A, Donaldson D, Kiely T, Wu L. Pesticides Industry Sales and Usage: 2006 and 2007 Market Estimates. Office of Pesticide Programs, Office of Chemical Safety and Pollution Prevention, U.S. Environmental Protection Agency, Washington, D.C, 2011.

[23] Eisler R. Diazinon Hazards to Fish, Wildlife, and Invertebrates: A Synoptic Review. Contaminant Hazard Reviews Report No. 9. U.S. Department of the Interior, Fish and Wildlife Service, Laurel, 1986.

[24] Kegley S E, Hill B R, Orme S, Choi A H. PAN pesticide database. Pesticide action network, North America. Available online at http://www.pesticideinfo.org/List

Chemicals, 2014.
[25] Cyco'n M, W'ojcik M, Piotrowska-Seget Z. Biodegradation of the organophosphorus insecticide diazinon by Serratia $\mathrm{sp}$. and Pseudomonas sp. and their use in bioremediation of contaminated soil. Chemosphere, 2009, 76, 494-501.

[26] Cyco'n M, Zmijowska A, W'ojcik M, Piotrowska-Seget Z. Biodegradation and bioremediation potential of diazinon degrading Serratia marcescens to remove other organophosphorus pesticides from soils. J Environ Manage, 2013, 117, 7-16.

[27] Deng S Y, Chen Y, Wang D S, Shi T Z, Wu X W, Ma X, Li X Q, Hua R M, Tang X Y, Li Q X. Rapid biodegradation of organophosphorus pesticides by Stenotrophomonas sp. G1. J Hazard Mater, 2015, 297, 17-24. 